\title{
Periphyton support for littoral secondary production in a highly humic boreal lake
}

\author{
Jussi Vesterinen ${ }^{1,4}$, Jari Syväranta ${ }^{1,2,5}$, Shawn P. Devlin ${ }^{1,3,6}$, and Roger I. Jones ${ }^{1,7}$ \\ ${ }^{1}$ University of Jyväskylä, Department of Biological and Environmental Science, P.O. Box 35 FI-40014 University of Jyväskylä, Finland \\ ${ }^{2}$ Aarhus University, Department of Bioscience, Vejlsøvej 25, 8600 Silkeborg, Denmark \\ ${ }^{3}$ Flathead Lake Biological Station, University of Montana, Polson, Montana 59860 USA
}

\begin{abstract}
Steep stratification and poor light penetration in highly humic lakes typically restrict oxygenated littoral areas to narrow lake margins. However, in some instances, surrounding floating vegetation mats can sustain highly productive periphyton and more diverse invertebrate communities than pelagic areas. Little is known about how these littoral food webs function or the extent to which the pelagic and littoral food webs are coupled. We added ${ }^{15} \mathrm{~N}$-labeled ammonium nitrate to the floating moss mat surrounding the littoral zone of Mekkojärvi, a small highly humic and fishless lake in southern Finland. Our goal was to increase the $\delta^{15} \mathrm{~N}$ values of periphyton to investigate the diets of littoral invertebrates and possible pelagic-littoral coupling in the lake. We divided the lake in 2 with a plastic curtain and added European Perch (Perca fluviatilis) to 1 basin while the other remained fishless. $\delta^{15} \mathrm{~N}$ of periphyton and most littoral invertebrates increased well above the natural abundance levels. $\delta^{15} \mathrm{~N}$ of pelagic Daphnia generally did not increase, except for a sudden and transitory increase in the basin where fish were introduced. Only one perch of the 33 recaptured following their introduction showed clearly increased $\delta^{15} \mathrm{~N}$. The lowest $\delta^{13} \mathrm{C}$ values were found in pelagic invertebrates. Most littoral invertebrates had values closer to those of periphyton, which clearly contributed significantly to the diets of most littoral invertebrate groups and was an important basal resource in the littoral food web. Chironomids and ephemeropterans had surprisingly low $\delta^{13} \mathrm{C}$ values, which may reflect inclusion in their diets of highly ${ }^{13} \mathrm{C}$-depleted methane-oxidizing bacteria, which were known to contribute to the diets of Daphnia in the lake. Our results indicate that the pelagic and littoral habitats are not strongly coupled in the absence of fish but that zooplanktivorous fish may increase coupling by driving zooplankton into the littoral zone to seek refuge from predation.
\end{abstract}

Key words: littoral invertebrates, benthic algae, methane-oxidizing bacteria, stable-isotope analysis, isotope additions

Secondary production in lakes is fueled by autochthonous $\mathrm{C}$ from pelagic and benthic primary production (PP) and terrestrially derived allochthonous $\mathrm{C}$. The relative importance of these $\mathrm{C}$ sources in food webs varies among lakes. The allochthonous contribution generally increases in importance with decreasing light penetration into water (Ask et al. 2009, Karlsson et al. 2009, Solomon et al. 2011), a condition typical of humic lakes. Allochthonous C can support higher trophic levels via a microbial link in pelagic (Jones 1992, Pace et al. 2004) and benthic (Premke et al. 2010, Karlsson et al. 2012) food webs. However, colored allochthonous dissolved organic C (DOC) reduces light availability for phytoplankton and benthic algae, so it also constrains whole-lake primary production and ultimately secondary production (Karlsson et al. 2009, Jones et al. 2012). Moreover, allochthonous DOC promotes rapid warming of upper water layers after ice-off, leading to earlier development of very steep temperature and $\mathrm{O}_{2}$ stratification, especially in the small humic lakes that are abun- dant across the boreal region (Bowling and Salonen 1990). This stratification can lead to complete anoxia in the hypolimnion for most of the year, thereby effectively restricting zoobenthic production to oxic littoral areas close to the water surface. Thus, lakes with high DOC concentrations tend to have restricted oxygenated habitats and low zoobenthic production (Craig et al. 2015).

In clear-water lakes, profundal zoobenthos is mainly supported by sedimenting pelagic energy sources (Covich et al. 1999), whereas littoral zoobenthic communities mostly receive their energy from benthic PP by periphyton (Vander Zanden and Rasmussen 1999, Devlin et al. 2013). Nutrients increase phytoplankton biomass and result in reduced benthic PP because of shading (Vadeboncoeur et al. 2003, 2008). Investigators often assume that energy mobilization shifts from benthic and autotrophic toward pelagic and heterotrophic as increasing allochthonous $\mathrm{C}$ reduces light availability (Ask et al. 2009, Zwart et al. 2015). This assumption has led to the prevalent notion that littoral pri-

E-mail addresses: ${ }^{4}$ jussi.p.vesterinen@jyu.fi; ${ }^{5}$ jarsyv@bios.au.dk; ${ }^{6}$ shawn.devlin@flbs.umt.edu; ${ }^{7}$ roger.i.jones@jyu.fi

DOI: 10.1086/689032. Received 9 April 2016; Accepted 28 July 2016; Published online 28 September 2016.

Freshwater Science. 2016. 35(4):1235-1247. @ 2016 by The Society for Freshwater Science.

1235 
mary producers are of minor importance in the energy budgets of humic lakes. However, we recently demonstrated that PP by littoral periphyton dominated whole-lake PP in small, highly humic Lake Mekkojärvi (Vesterinen et al. 2016), contradicting predictions for the benthic fraction of whole-lake PP in such lakes according to the model presented by Vadeboncoeur et al. (2008). In Mekkojärvi, the floating littoral vegetation mat fringe supports highly productive periphyton communities just under the water surface under well-illuminated conditions. Gross PP by periphyton exceeded community respiration in the littoral zone and balanced whole-lake metabolism or made it net autotrophic (Vesterinen et al. 2016). The relative importance of allochthonous and autochthonous resources for secondary production in humic lakes continues to be debated, but the need to study the importance of such highly productive periphyton communities in humic lakes is obvious.

We investigated the possible consumption of littoral periphyton in Mekkojärvi by adding ${ }^{15} \mathrm{~N}$-enriched ammonium nitrate $\left({ }^{15} \mathrm{NH}_{4}{ }^{15} \mathrm{NO}_{3}\right)$ evenly around the littoral moss and macrophyte vegetation during summer 2014 to give the periphyton a distinctive ${ }^{15} \mathrm{~N}$ label. We then tracked the movement of that label into the littoral biofilm and into invertebrates and fish. We used ${ }^{15} \mathrm{NH}_{4}{ }^{15} \mathrm{NO}_{3}$ because previous experiments with dissolved inorganic $\mathrm{C}$ (DIC) labeling of the lake based on ${ }^{13} \mathrm{C}$-bicarbonate had shown that the addition frequency needed for strong labeling of DIC in $\mathrm{CO}_{2}$-supersaturated water would have been too laborious (Taipale et al. 2008). DIC concentrations, turnover rates, and atmospheric exchange can be even higher in the littoral than in the pelagic zone, making ${ }^{13} \mathrm{C}$-labeling of periphyton particularly problematic. We also were able to study the extent to which the pelagic and littoral food webs in the lake were coupled because the naturally fishless lake had been split with a plastic curtain and fish had been introduced to one of the basins (see Devlin et al. 2015). Coupling of pelagic and littoral habitats can occur directly via movement of fish between habitats (Schindler and Scheuerell 2002) and indirectly via horizontal migrations of zooplankton from the pelagic to the littoral zone where they seek refuge from fish predation (Van de Meutter et al. 2004). We hypothesized that: 1) the highly productive periphyton communities in the lake contribute significantly to the invertebrate food web in the littoral zone, 2) predatory taxa within the littoral zoobenthic community could be partly supported by consumption of Daphnia of pelagic origin, and 3) introduction of fish would promote coupling of the littoral and pelagic food webs.

\section{METHODS}

\section{Study lake}

Mekkojärvi is a small (0.35 ha) and highly humic headwater lake in the Evo forest region in southern Finland (lat $61^{\circ} 13^{\prime} \mathrm{N}$, long $25^{\circ} 3^{\prime} \mathrm{E}$; Fig. 1). The mean and maximum depths are 2 and $4.3 \mathrm{~m}$, respectively. The lake is sheltered by coniferous forest and receives a high loading of terrestrial organic matter from its catchment causing high DOC concentrations (water color ranges from $300-800 \mathrm{mg} \mathrm{Pt} / \mathrm{L}$ ) and low $\mathrm{pH}$. The high DOC, in turn, causes the lake to develop very steep temperature and $\mathrm{O}_{2}$ gradients immediately after ice melt in spring. The thermocline lies between 0.5 and $1.0 \mathrm{~m}$, and anoxia occurs under that layer. Mekkojärvi becomes totally anoxic during winter under ice and, therefore, cannot sustain natural fish populations. Details of the lake's physical and chemical characteristics are presented elsewhere (e.g., Devlin et al. 2015, Vesterinen et al. 2016). The absence of planktivorous fish normally leads to the development of dense populations of the large bodied cladoceran Daphnia longispina in summer. Mekkojärvi has a depth ratio $\left(\mathrm{DR}=\bar{z} / z_{\max }\right.$, where $z=$ depth) of 0.47 , so the lake is steep-sided and lacks illuminated benthic surfaces because of the highly colored water and very low light penetration (light-attenuation coefficient, $K_{d}$, ranges from 4.5 to 7.5 ; Vesterinen et al. 2016). The littoral zone is not clearly defined, but most of the lake's perimeter is covered by a floating vegetation mat consisting mainly of Sphagnum and Warnstorfia moss species with some fallen terrestrial sedges (Carex spp.), emergent macrophytes (Menyanthes trifoliata, Phragmites australis), and Utricularia sp. associated with the moss. This surrounding littoral vegetation does not extend $>1 \mathrm{~m}$ from the lake edge and not deeper than $\sim 0.5 \mathrm{~m}$, but provides habitat for macroinvertebrate populations and supports highly productive periphyton assemblages (Vesterinen et al. 2016) that develop rapidly in spring and achieve their highest biomass in summer. Daphnia longispina is the predominant invertebrate in the pelagic zone, which is relatively poor in other invertebrate taxa, but the littoral vegetation mat supports a more diverse invertebrate community (Table S1).

During our study, Mekkojärvi was divided with a plastic curtain. The absence of overwintering fish populations in the lake allowed us to introduce adult European Perch (Perca fluviatilis) to one basin (designated Fish+), while the other remained fishless (designated Fish-) (Fig. 1), and hence, to investigate the possible influence of fish on pelagiclittoral coupling in the 2 fish treatments. Perch of length ranging from 10 to $15 \mathrm{~cm}$ were trapped from nearby Lake Horkkajärvi and introduced into Mekkojärvi in early July each year with a biomass mimicking the typical natural biomass of perch in local lakes $\left(1-2 \mathrm{~g} / \mathrm{m}^{2}\right.$; Natural Resource Institute Finland), in proportion to the volume of oxic water in Mekkojärvi.

\section{Sampling procedure, isotope additions, and stable-isotope analysis (SIA)}

We sampled periphyton for SIA during the open water seasons in 2011-2013 to estimate temporal variation in the natural abundance $\delta^{15} \mathrm{~N}$ values. During these years, 


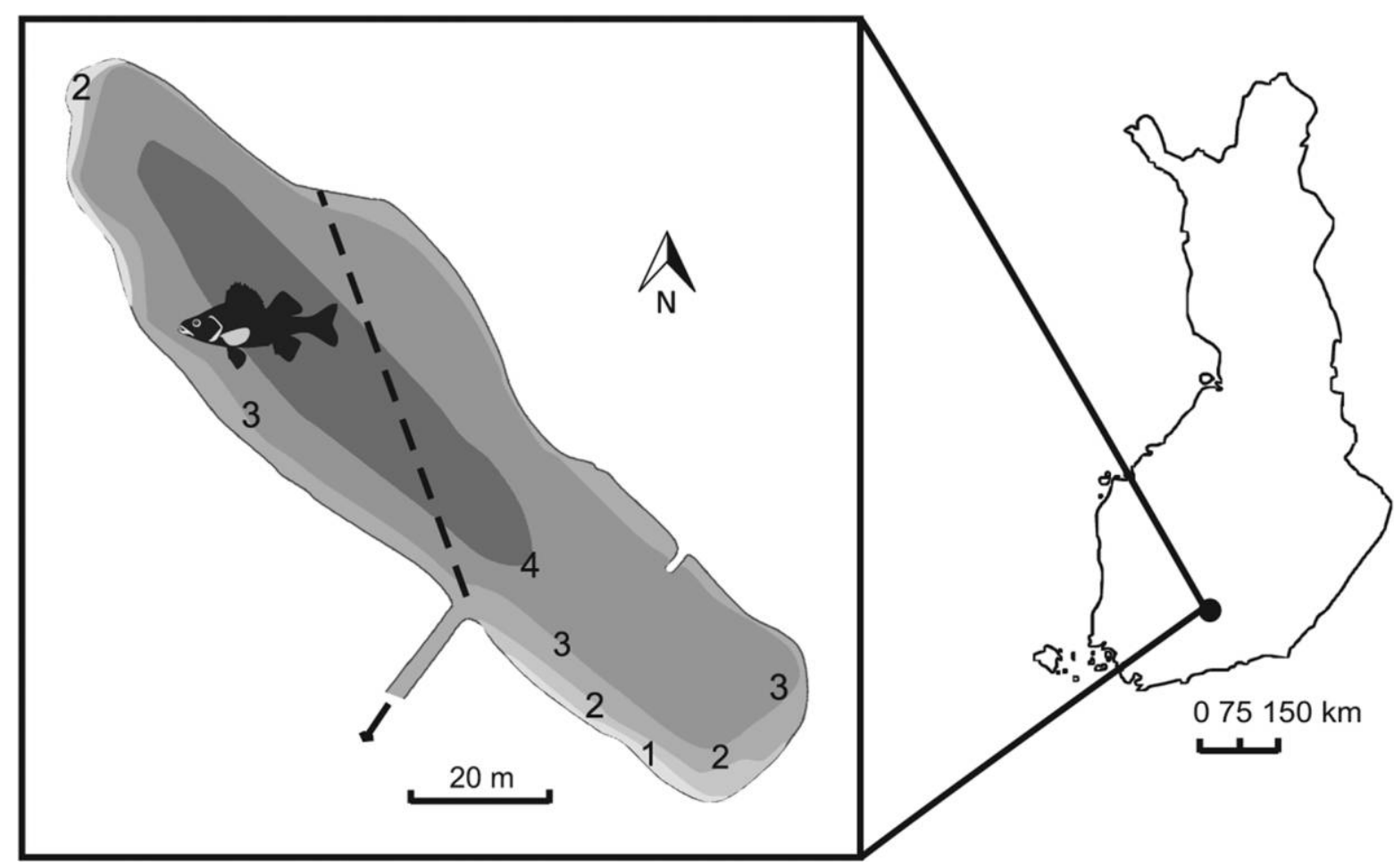

Figure 1. Location and bathymetry (numbers indicate depth contours in $\mathrm{m}$ ) of Mekkojärvi. The dashed line illustrates the location of the dividing curtain and the fish symbol identifies the basin to which fish were introduced.

${ }^{15} \mathrm{NH}_{4}{ }^{15} \mathrm{NO}_{3}$ had been added to the pelagic area once or twice per summer as part of a previous isotope addition experiment, but these additions had no detectable effect on the littoral communities (see below).

In 2014, we sampled periphyton on 29 May and 4 June to estimate initial $\delta^{15} \mathrm{~N}$ values before making isotope additions. Later in 2014, we spread 200 to $250 \mathrm{mg}$ of ${ }^{15} \mathrm{NH}_{4}{ }^{15} \mathrm{NO}_{3}$ onto the littoral moss and macrophyte vegetation surrounding the lake to increase the $\delta^{15} \mathrm{~N}$ signature of periphyton and to make it more distinct from other potential basal resources (phytoplankton and allochthonous organic matter) in the lake. We assumed that the highly productive periphyton communities would take up all the added $\mathrm{N}$ quickly and, thus, would effectively restrict the labeling to littoral areas. We calculated an appropriate addition of ${ }^{15} \mathrm{NH}_{4}{ }^{15} \mathrm{NO}_{3}$ according to Fry (2006b) based on measured $\mathrm{NH}_{4}{ }^{+}$and $\mathrm{NO}_{3}{ }^{-}$concentrations in the lake's epilimnion. The ${ }^{15} \mathrm{NH}_{4}{ }^{15} \mathrm{NO}_{3}$ was first diluted into $2 \mathrm{~L}$ of distilled water, which was further diluted into $40 \mathrm{~L}$ of lake water. The diluted label was then spread evenly around the lake littoral zone with a watering can from a rowboat. The amount of ${ }^{15} \mathrm{NH}_{4}{ }^{15} \mathrm{NO}_{3}$ needed for strong labeling was small compared to the combined natural $\mathrm{NH}_{4}{ }^{+}, \mathrm{NO}_{3}{ }^{-}$, and $\mathrm{NO}_{2}$ concentrations in the lake $\left(\sim 70 \mathrm{mg} \mathrm{N} / \mathrm{m}^{3}\right.$ in the epilimnion; Vesterinen et al. 2016), so we were not concerned that the ${ }^{15} \mathrm{~N}$ additions would cause a fertilization effect. We added ${ }^{15} \mathrm{NH}_{4}{ }^{15} \mathrm{NO}_{3}$ for the first time on 24 June, with further additions on 14 and 29 July and 1 Septem- ber. After the first addition, we analyzed preliminary samples. We subsequently increased the amount of label from 200 to $250 \mathrm{mg}$ to enhance the labeling. We sampled periphyton before each addition of ${ }^{15} \mathrm{~N}$ and a few days later to measure the increase in the $\delta^{15} \mathrm{~N}$ value, and then $\sim 1 \mathrm{wk}$ later to measure the decrease in the label. We used this process to assess the temporal variation of the $\delta^{15} \mathrm{~N}$ during the experiment.

We randomly selected 8 subsamples of moss and macrophyte pieces from all around the lake and used a spatula to scrape the associated periphyton into cryogenic vials. We took the samples to the nearby laboratory at Lammi Biological Station (University of Helsinki) where they were cleaned of any remaining associated plant pieces, frozen, and later freeze-dried (Christ Alpha 1-4 LD plus; Martin Christ, Osterode, Germany). We sampled pelagic particulate organic matter (POM) 3 times in June-August 2014 after the isotope additions. To measure the $\delta^{13} \mathrm{C}$ and $\delta^{15} \mathrm{~N}$ values of particulate organic matter (POM), we filtered $500 \mathrm{~mL}$ of lake water through pre-ignited Whatman GF/F glass-fiber filters (nominal pore size $=0.7 \mu \mathrm{m}$ ), which we then dried. We scraped the retained material into Sn capsules (see below).

In 2014, we used a hand net (mesh size $=500 \mu \mathrm{m}$ ) to collect macroinvertebrates and littoral zooplankton from a rowboat. We rowed around the lake and pulled the hand net around the shoreline on the moss while we took random moss and macrophyte samples. We placed all the 
hand-net hauls from both basins in plastic buckets, took the samples to the laboratory, and picked out all littoral macroinvertebrate and zooplankton taxa that were sufficiently abundant for SIA. We sampled pelagic zooplankton with a standard plankton net (mesh size $=50 \mu \mathrm{m}$; Limnos, Komorów, Poland) either by vertical hauls or, if zooplankton was scarce, by rowing around the pelagic area and pulling the plankton net behind the boat. We identified all invertebrates to family or genus level and oven-dried them at $60^{\circ} \mathrm{C}$ for $48 \mathrm{~h}$ at Lammi Biological Station. We recaptured perch introduced to the Fish+ basin with traps during August to October and placed them on ice before measuring and weighing them in the laboratory. We dissected a small piece of dorsal muscle from each fish and placed it in an Eppendorf tube. We froze and then freezedried the muscle tissue (Christ Alpha 1-4 LD plus).

We ground each dried sample for SIA to a fine powder with a mortar and pestle and accurately weighed $\sim 0.6$ (invertebrates and fish) or $1.5 \mathrm{mg}$ (periphyton and POM) of sample into a Sn capsule. Sample C and N isotopic composition was analyzed at the University of Jyväskylä with a FlashEA 1112 elemental analyzer (Thermo Electron Corporation, Waltham, Massachusetts) coupled to a Thermo Finnigan DELTAplus Advantage mass spectrometer (Thermo Electron Corporation). Internal laboratory working standards were pulverized pike muscle tissue for macroinvertebrate and fish and pulverized potato leaves for periphyton and POM samples. To ensure accurate analysis and correction for possible drift and linearity, replicate standards were run repeatedly in every analysis (standard deviation [SD] for both $\delta^{13} \mathrm{C}$ and $\delta^{15} \mathrm{~N}$ was always $<0.2 \%$ o).

\section{Statistical analyses}

We used 1-way analysis of variance (ANOVA) with Tukey post hoc tests to test for differences in natural abundance $\delta^{15} \mathrm{~N}$ of periphyton among years 2011-2013. For the 2014 data, we used repeated measures of analysis of variance (rmANOVA) to test for differences in $\delta^{15} \mathrm{~N}$ of periphyton among sampling occasions (dependent variable/within-subject variable) and between treatment basins (grouping variable/between-subject factor). We used Welch's $t$-test to test for differences of $\delta^{13} \mathrm{C}$ and $\delta^{15} \mathrm{~N}$ of macroinvertebrates when the assumptions of equal sampling sizes and homogeneity of variances were not met. We also used Welch's $t$-test to test for differences in invertebrate and fish $\delta^{15} \mathrm{~N}$ values (dependent variables) between dates (independent variable) and to test for differences in pooled invertebrate $\delta^{15} \mathrm{~N}$ values (dependent variables) before and after the isotope additions (time as an independent variable). We used Durbin-Watson statistics to detect possible autocorrelation in $2014 \delta^{15} \mathrm{~N}$ data sets for periphyton and invertebrates. We conducted all statistical tests with IBM SPSS Statistics (version 20.0.0.2; IBM, Armonk, New York).

To investigate the relative contributions of periphyton, allochthonous $\mathrm{C}$, and methane-oxidizing bacteria (MOB) to littoral invertebrate diets we used the Bayesian mixing model SIAR (Parnell et al. 2010). We ran the model for combined nonpredatory taxa (herbivorous or detritivorous taxa [herbi-detritivores]) because they are the primary consumers of these basal sources. We compared the models for the invertebrate isotope data from years with (2014) and without (2013) isotope additions to the littoral zone. We obtained input isotope values for SIAR mixing model diet sources (Table S2) as follows. For periphyton, we used the averages over the whole sampling period in 2013 and the averages from the start of the isotope additions to the end of the sampling period in 2014. We derived isotope values for allochthonous organic matter (OM) from POM values, $\delta^{13} \mathrm{C}$ of which ranged between -29 and $-27 \%$ and were consistent with values for allochthonous DOC and allochthonous organic C users in Mekkojärvi (Taipale et al. 2007). For MOB, we used isotope values published by Taipale et al. (2008). For consumers in 2013, we used the averages over the whole sampling period, and in 2014, we used the averages from September to October when the $\delta^{15} \mathrm{~N}$ values had reached their maximum or started to decrease slightly. We used trophic fractionation factors of $2.52 \pm 2.5$ for $\delta^{15} \mathrm{~N}$ and $0.47 \pm 1.23$ for $\delta^{13} \mathrm{C}$ according to Vander Zanden and Rasmussen (2001). Before the SIAR model was run, we evaluated model uncertainty for $2 \mathrm{y}$ with Monte Carlo simulations for mixing polygons defined by the putative food sources (Smith et al. 2013) to resolve whether consumer values lay within the 95\% mixing region. We ran Bayesian SIAR mixing models and Monte Carlo simulations of mixing polygons in $\mathrm{R}$ (version 3.2.3; R Project for Statistical Computing, Vienna, Austria).

\section{RESULTS}

\section{Previous pelagic isotope additions in 2013}

The previous ${ }^{15} \mathrm{NH}_{4}{ }^{15} \mathrm{NO}_{3}$ additions to the pelagic zone in June and August 2013 had clearly increased the bulk mean $\delta^{15} \mathrm{~N}$ values of POM (Fig. 2A) and pelagic Daphnia (Fig. 2B) with maximum values ranging between 20 and $30 \%$. Peak $\delta^{15} \mathrm{~N}$ values for POM and Daphnia were very similar in both basins, except that in late August the Daphnia $\delta^{15} \mathrm{~N}$ declined more rapidly in the Fish+ treatment than in the Fish- basin. However, these pelagic ${ }^{15} \mathrm{~N}$ additions had no marked effect on the mean $\delta^{15} \mathrm{~N}$ of periphyton or littoral invertebrates (Fig. 2C). Moreover, in 2011 and 2012, when only a single pelagic ${ }^{15} \mathrm{~N}$ addition was made, the mean $( \pm \mathrm{SD}) \delta^{15} \mathrm{~N}$ values of littoral invertebrates were respectively $4.4 \pm 1.1$ and $3.9 \pm 1.56 \%$ o, indicating no spread of label to the littoral zone.

\section{Response of littoral communities to ${ }^{15} \mathrm{~N}$ additions to the littoral zone}

The mean $( \pm \mathrm{SD})$ natural abundance $\delta^{15} \mathrm{~N}$ values of periphyton during 2011-2013 were low (mean of all sam- 

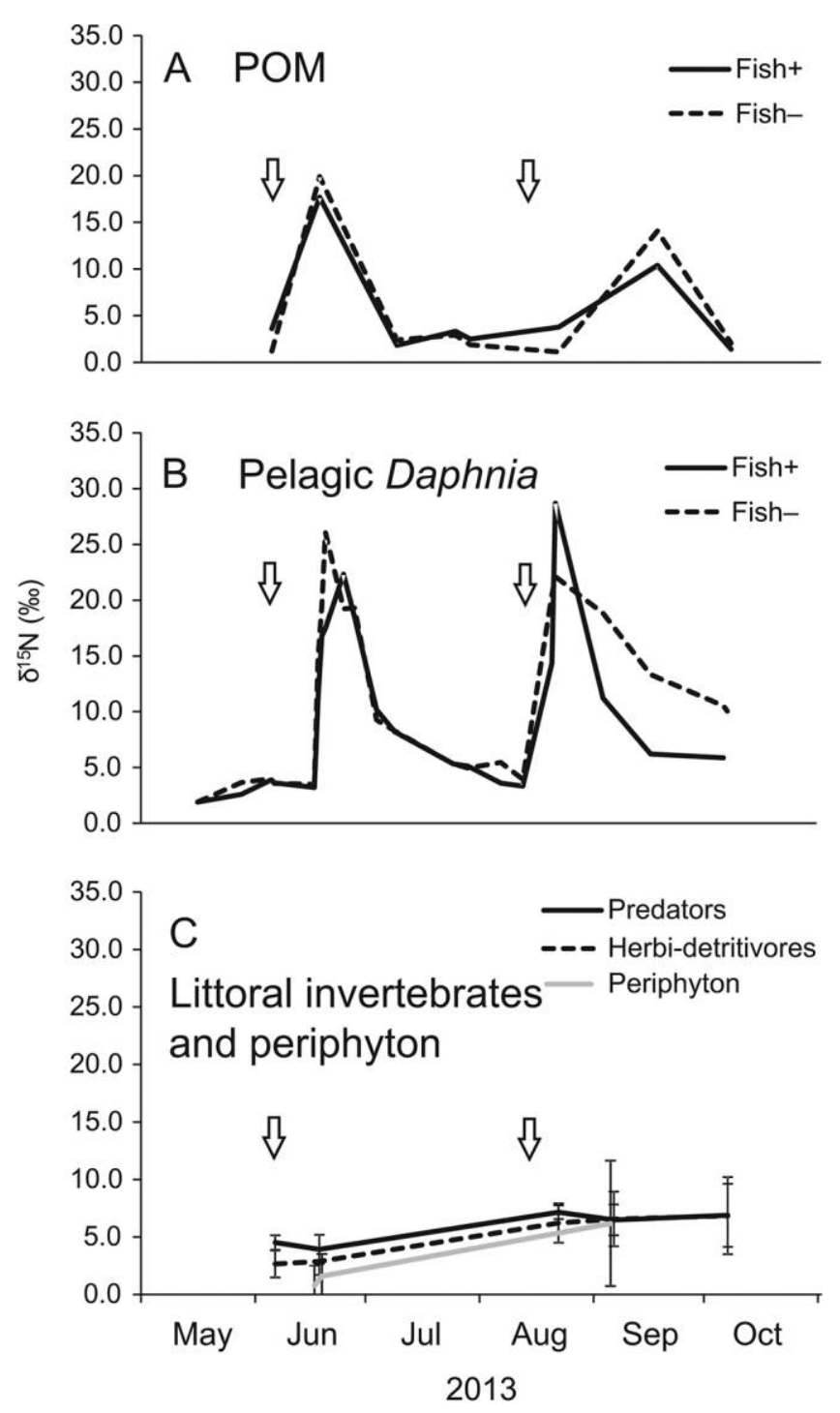

Figure 2. The mean $\delta^{15} \mathrm{~N}$ of particulate organic matter (POM) (A) and pelagic Daphnia (B) for both basins, and mean $( \pm \mathrm{SD})$ $\delta^{15} \mathrm{~N}$ values pooled from both basins for littoral invertebrates in 2013 (C). The arrows indicate the dates of ${ }^{15} \mathrm{~N}$ additions.

ples $=2.2 \pm 2.3 \%$; Fig. $3 \mathrm{~A}) \cdot \delta^{15} \mathrm{~N}$ values of periphyton differed among dates (1-way ANOVA, $F_{8,31}=2.88, p<$ $0.05)$. From June to July, $\delta^{15} \mathrm{~N}$ increased significantly from $-0.6 \pm 0.5$ to $4.8 \pm 3.9 \%$ o (Tukey's test, $p<0.05$ ), indicating either natural variation or some small reflection of the pelagic isotope additions. The $\delta^{15} \mathrm{~N}$ values of periphyton in 2014 before the first littoral ${ }^{15} \mathrm{~N}$ addition (Fig. 3B) were consistent with the values from earlier years and varied between $-0.3 \pm 1.0$ and $0.9 \pm 1.9 \%$ o. ${ }^{15} \mathrm{~N}$ labeling of the periphyton was effective. Each isotope addition to the littoral zone generated a rapid increase in periphyton $\delta^{15} \mathrm{~N}$ followed by a more gradual decline. The highest periphyton $\delta^{15} \mathrm{~N}$ value $(108.5 \pm 87.4 \%$ ) was measured on 9 August after the $3^{\text {rd }}$ addition. The mean periphyton $\delta^{15} \mathrm{~N}$ over the whole 2014 sampling period was $32.7 \pm 47.0 \%$. The 2 ba- sin treatments, Fish+ and Fish-, showed very similar patterns, but with some differences in the magnitude of peaks (Fig. 3C). No autocorrelation was detected in either basin (Durbin-Watson upper limit $[d \mathrm{U}]=1.54$; Fish+: $d=1.654$, $n=48$; Fish-: $d=1.674, n=47$ ). Spatial variation in the complex littoral habitat was rather high, and significant differences in the labeling of periphyton was detected between basins. rmANOVA revealed a significant main effect of time $\left(F_{11,66}=8.35, p<0.01\right)$, which was not affected by basin treatments $\left(F_{11,66}=0.83, p=0.46\right)$. The initial $\delta^{15} \mathrm{~N}$
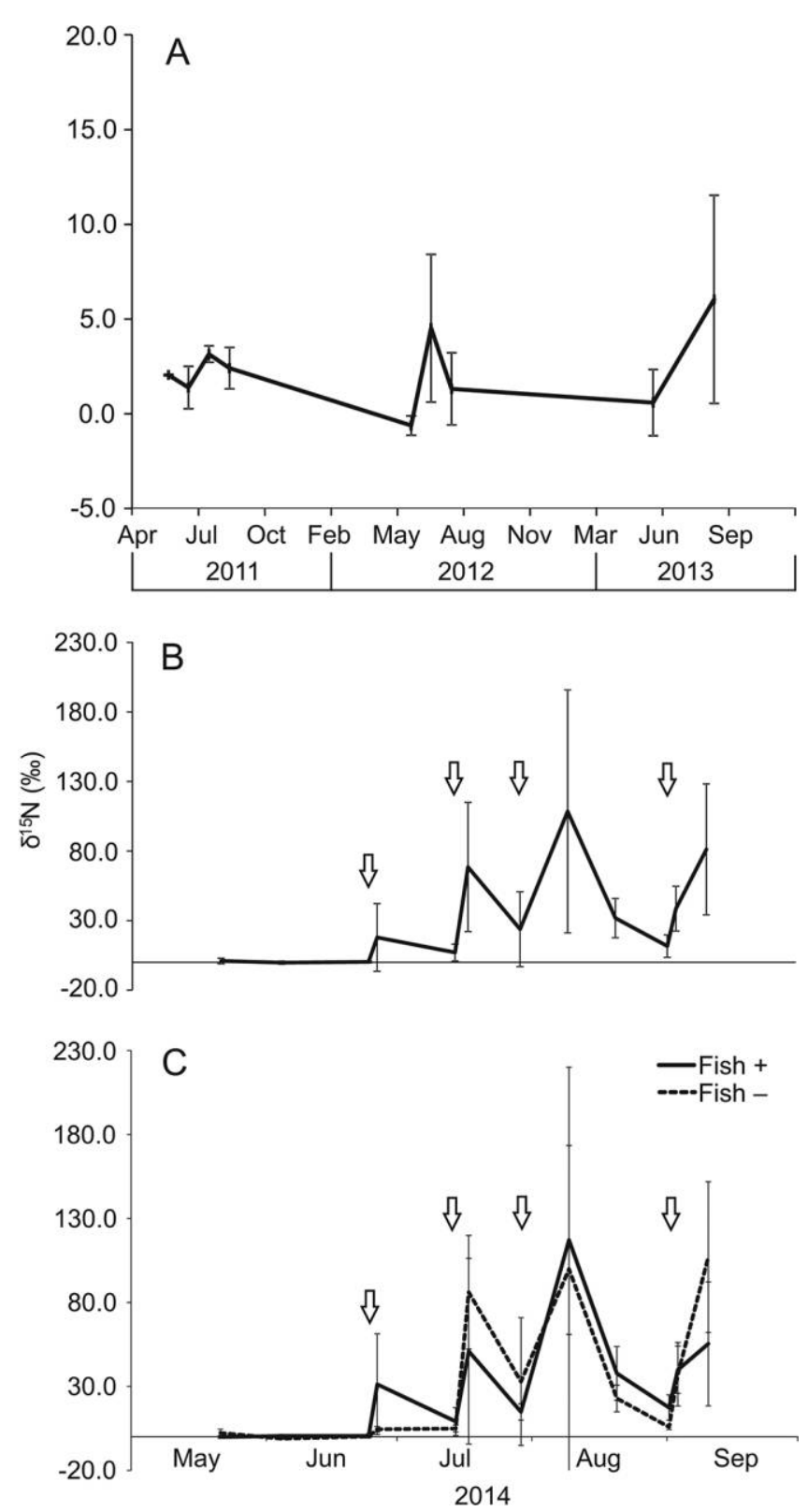

Figure 3. The whole-lake mean $( \pm \mathrm{SD}) \delta^{15} \mathrm{~N}$ values of periphyton during $2011-2013$ (A) and in 2014 when ${ }^{15} \mathrm{~N}$ label was first added to the littoral zone on 24 June (B), and the mean values for each treatment basin in 2014 (C). In B and C the arrows indicate the dates of ${ }^{15} \mathrm{~N}$ additions. 
values differed significantly from all values after the isotope additions (Tukey's test, $p<0.05$ ).

Hand-net sampling for littoral invertebrates and planktonnet sampling for pelagic zooplankton yielded 20 repeatedly occurring invertebrate taxa from Mekkojärvi (Table S1). Some taxa, like Ephemeroptera and Trichoptera, were difficult to find in spring and early summer but were notably more abundant later in the year. We did not calculate the total richness of taxa or the total abundances of individuals, but the invertebrate community in the littoral zone appeared to be dominated by predators with high proportions of Anisoptera and Cyclopoida, as reported in previous studies in Mekkojärvi (Kairesalo et al. 1992, Zúñiga 2011).

The ${ }^{15} \mathrm{~N}$ label added to the littoral zone in 2014 was transferred effectively to littoral consumers. Before the ${ }^{15} \mathrm{~N}$ additions, mean $\delta^{15} \mathrm{~N}$ value of herbi-detritivores was $5.4 \pm$ $2.0 \%$ in the Fish+ basin and $5.2 \pm 2.5 \%$ in the Fish- basin (Fig. 4A). For predators, the respective values were $4.6 \pm$

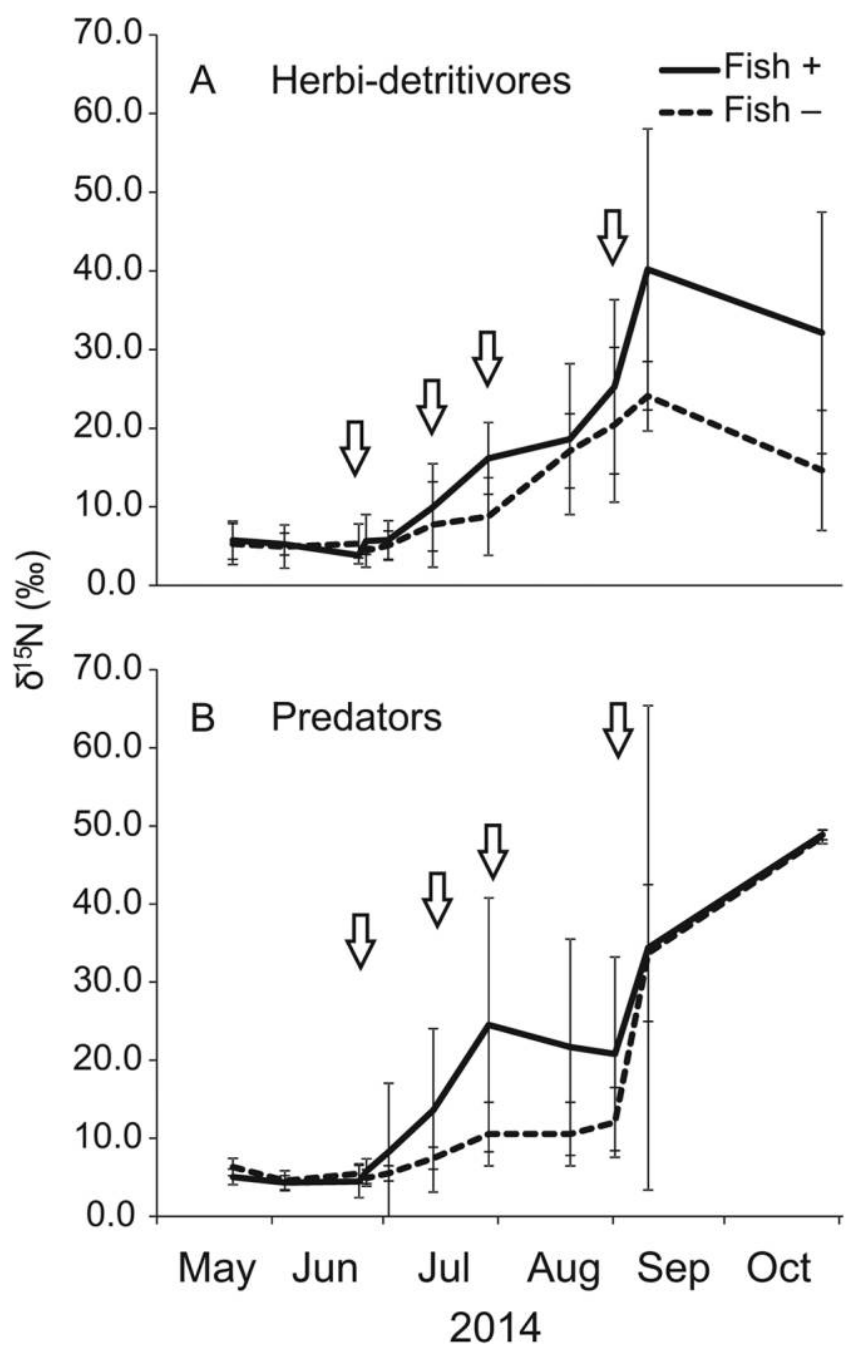

Figure 4. Mean $( \pm \mathrm{SD}) \delta^{15} \mathrm{~N}$ values of herbi-detritivore (A) and predator (B) littoral macroinvertebrates for both treatment basins in 2014. The arrows indicate the dates of ${ }^{15} \mathrm{~N}$ additions.
1.3 and $5.5 \pm 1.4 \%$ o (Fig. $4 \mathrm{~B}$ ). The $\delta^{15} \mathrm{~N}$ values of littoral macroinvertebrates began to increase in both basins soon after the first isotope addition in late June and appreciably faster in the Fish+ basin. Periphyton was already strongly ${ }^{15} \mathrm{~N}$ labeled in July, but a lag was present in the accumulation of the label in the consumers, with highest macroinvertebrate $\delta^{15} \mathrm{~N}$ values recorded in September-October. This lag was particularly marked for predators (Fig. 4B), which exhibited highest $\delta^{15} \mathrm{~N}$ values (Fish+: $48.9 \pm 0.6$, Fish-: $48.6 \pm 0.9 \%$ ) in late October, whereas the $\delta^{15} \mathrm{~N}$ of herbi-detritivores (Fig. 4A) had started to decrease by late autumn but remained higher in the Fish+ than in the Fishbasin. Mean $\delta^{15} \mathrm{~N}$ of herbi-detritivores over the whole period of ${ }^{15} \mathrm{~N}$ additions was $20.5 \pm 16.0$ in the Fish + and $13.0 \pm$ $8.0 \%$ in the Fish- basin. For predators, the respective values were $20.3 \pm 17.9$ and $14.0 \pm 14.2 \%$. Herbi-detritivore data showed a positive autocorrelation in the Fish- (DurbinWatson lower limit $[d L]=1.61 ; d=1.052, n=94$ ) but not in the Fish+ basin $(d=1.692, n=78)$. Predators showed a positive autocorrelation in both basins $(d L=1.598$; Fish+: $d=1.479, n=74$; Fish-: $d=1.106, n=85)$. The only significant differences between basins were observed for herbi-detritivores on 27 October (Welch's $t$-test, $t_{1,13.7}=$ $13.9, p<0.01$ ) and for predators on 21 May (Welch's $t$-test, $\left.t_{1,18.9}=8.4, p<0.05\right)$. When the data from the 2 basins were pooled, the increase in $\delta^{15} \mathrm{~N}$ of predators from the initial values was significant (Welch's $t$-test, $t_{1,112.4}=58.1$, $p<0.01$ ), as was the increase for herbi-detritivores (Welch's $t$-test, $\left.t_{1,110.8}=73.3, p<0.01\right)$. However, caution is needed when interpreting these results because some autocorrelation was found in the invertebrate data sets.

\section{Response of zooplankton and fish to ${ }^{15} \mathrm{~N}$ additions to the littoral zone}

Pelagic zooplankton biomass was dominated by $D$. longispina. Within 1 mo of the introduction of perch to the Fish+ treatment basin, Daphnia had declined to such low abundance that we were unable to obtain enough sample material for SIA. Daphnia biomass remained high in the Fish- basin. $\delta^{15} \mathrm{~N}$ value of pelagic Daphnia in both basins was $\sim 3.0$ before addition of ${ }^{15} \mathrm{~N}$ label to the littoral zone (Fig. 5A), similar to the early summer values from 2013 (Fig. 2B). After ${ }^{15} \mathrm{~N}$ addition, the $\delta^{15} \mathrm{~N}$ values of Daphnia in the Fish- basin did not increase above 13.7\%o (10 September) and were mostly $<10.0 \%$ (Fig. $5 \mathrm{~A}$ ), suggesting some small influence of the label. In contrast, a much higher $\delta^{15} \mathrm{~N}$ value of 23.6\% was recorded for Daphnia from the Fish+ basin on 17 July, 2 wk after fish were introduced (Fig. 5A). On the next sampling occasion, 29 July, almost all Daphnia had been grazed from the Fish+ basin, and the $\delta^{15} \mathrm{~N}$ value had decreased to $11.8 \%$. The Daphnia in the last sample from the Fish+ basin consisted of very small individuals, most likely from a new pelagic generation with lower $\delta^{15} \mathrm{~N}$ values. The bulk mean $\delta^{15} \mathrm{~N}$ of littoral Cyclopoida (Fig. 5B) 

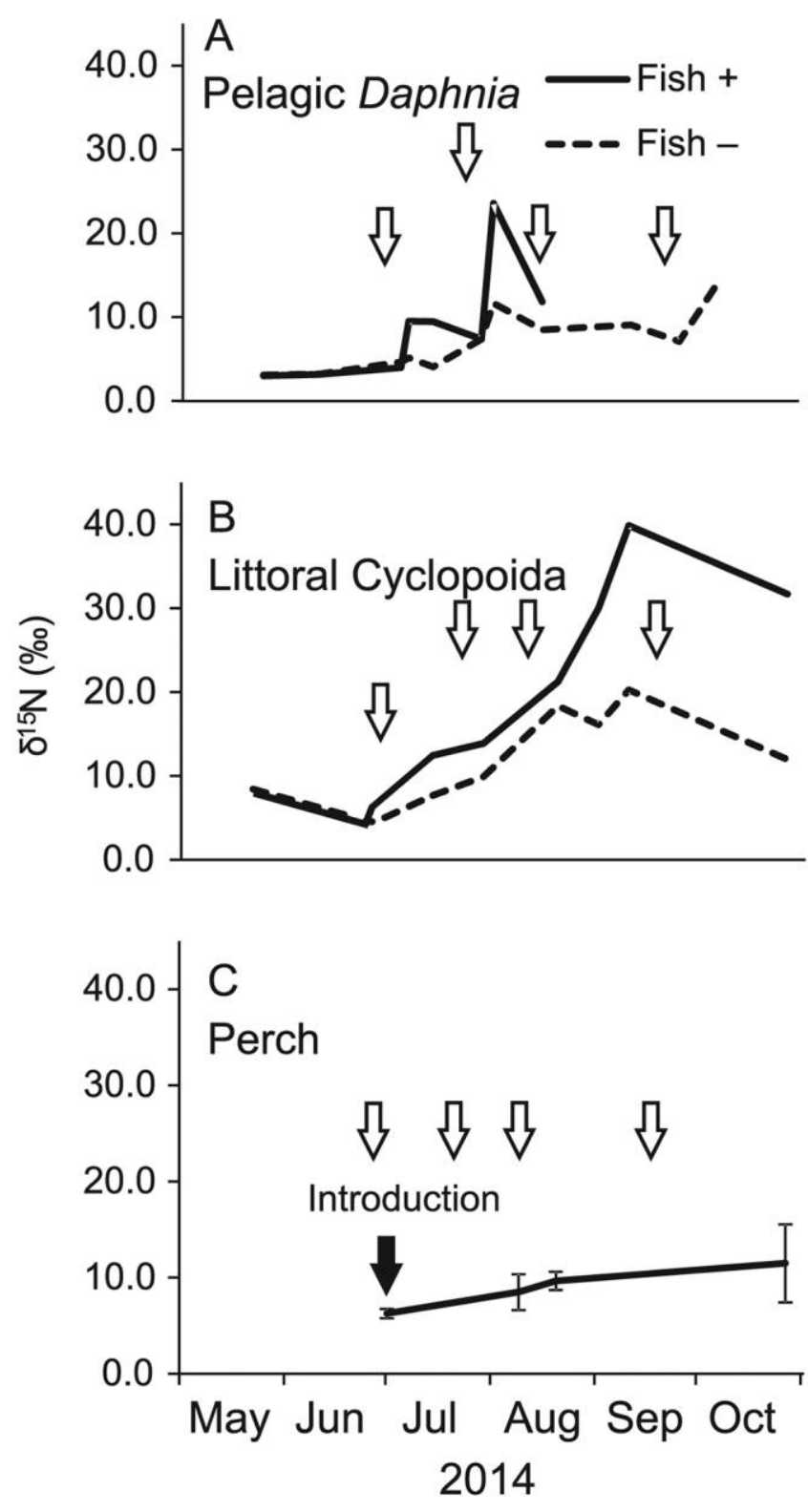

Figure 5. The mean $\delta^{15} \mathrm{~N}$ values of pelagic Daphnia (A) and littoral Cyclopoida (B) for both basins in 2014, and the mean $( \pm \mathrm{SD}) \delta^{15} \mathrm{~N}$ values of perch recaptured following their introduction to the Fish+ basin $(C)$. The white arrows indicate the dates of ${ }^{15} \mathrm{~N}$ additions, and the black arrow indicates the date of fish introduction.

showed a rather similar pattern in both basins, increasing through the open-water period and then declining in autumn, but reached higher values in the Fish+ than in the Fish- basin.

Perch were caught on 3 occasions after their introduction on 1 July. A slight but statistically significant (Welch's $t$-test, $\left.t_{3,7.5}=29.6, p<0.001\right)$ increase in the mean $\delta^{15} \mathrm{~N}$ of perch occurred during their time in the lake, from an initial value of $6.3 \pm 0.5$ to $11.5 \pm 4.0 \%$ on 27 October (Fig. 5 C).
One perch of the 33 recaptured individuals had a clearly higher $\delta^{15} \mathrm{~N}$ value of 23.2\%o (27 October).

\section{Foodweb relations and diets of herbi-detritivores}

An isotope biplot for $\delta^{15} \mathrm{~N}$ and $\delta^{13} \mathrm{C}$ values from 2014 indicated considerable separation of foodweb components (Fig. 6). Mean consumer $\delta^{13} \mathrm{C}$ values varied widely between -40.6 (for the rotifer Polyarthra) and -27.5\%o (for Gerridae), and significant differences were observed among taxa (Welch's $t$-test, $t_{15,49.9}=39.7, p<0.001$ ). The pelagic zooplankton Daphnia and Polyarthra had more negative $\delta^{13} \mathrm{C}$ values than all other groups except ephemeropterans and chironomids, which had the lowest $\delta^{13} \mathrm{C}$ values among the littoral invertebrate taxa (Tukey's tests, $p<0.05$ ). The potential food sources (periphyton: $\delta^{13} \mathrm{C}=-30.6 \pm 4.4 \%$, pelagic POM: $\delta^{13} \mathrm{C}=-29.1 \pm 0.7 \%$ ) were far less depleted in ${ }^{13} \mathrm{C}$ than pelagic invertebrates, whereas ${ }^{13} \mathrm{C}$ of most littoral invertebrates were between those of food sources and pelagic invertebrates. Periphyton $\delta^{13} \mathrm{C}$ values differed significantly from those of all invertebrate groups except Asellus, Araneae, Cyclopoida, Hydrachnidiae, Anisoptera, and Zygoptera (Tukey's tests, $p<0.05$ ).

Results of the SIAR mixing models are presented in Fig. 7A-K. According to the mixing polygons used to evaluate uncertainty in the SIAR mixing model (Fig. 7E, K), the isotope data for 2014 were a much better fit to the SIAR model than the 2013 data. All the consumer values in 2014 lay within the $95 \%$ mixing polygon (Fig. $7 \mathrm{~K}$ ), whereas several values from the 2013 data fell outside the region (Fig. 7E). Therefore the SIAR mixing model outputs for 2014, when the ${ }^{15} \mathrm{~N}$ additions were made to the littoral, can be considered more robust than those for 2013. The model for the 2014 data (Fig. 7F-J) was able to distinguish the contributions of the 3 food sources in consumer diets more clearly than for the 2013 data (Fig. 7A-D), when allochthonous C and periphyton overlapped in the diets of all consumers. The modeled 2014 data showed that the relative importance of periphyton was high for Asellus (Fig. 7F), Trichoptera (Fig. 7G), and Ephemeroptera (Fig. 7J), whereas allochthonous $\mathrm{C}$ was of high importance for Corixidae (Fig. $7 \mathrm{H}$ ), and both allochthonous $\mathrm{C}$ and $\mathrm{MOB}$ were important for Chironomidae (Fig. 7I).

\section{DISCUSSION}

Our results demonstrate that periphyton can be a significant basal resource even in highly humic lakes. Similar results have recently been reported from dystrophic lakes in Sweden (Lau et al. 2014) and humic bog pools in Estonia (van Duinen et al. 2013). The restricted light penetration into humic lakes commonly constrains pelagic and benthic primary production and ultimately secondary production (Karlsson et al. 2009, Jones et al. 2012), but littoral vegetation can provide substrata for substantial periphyton growth 


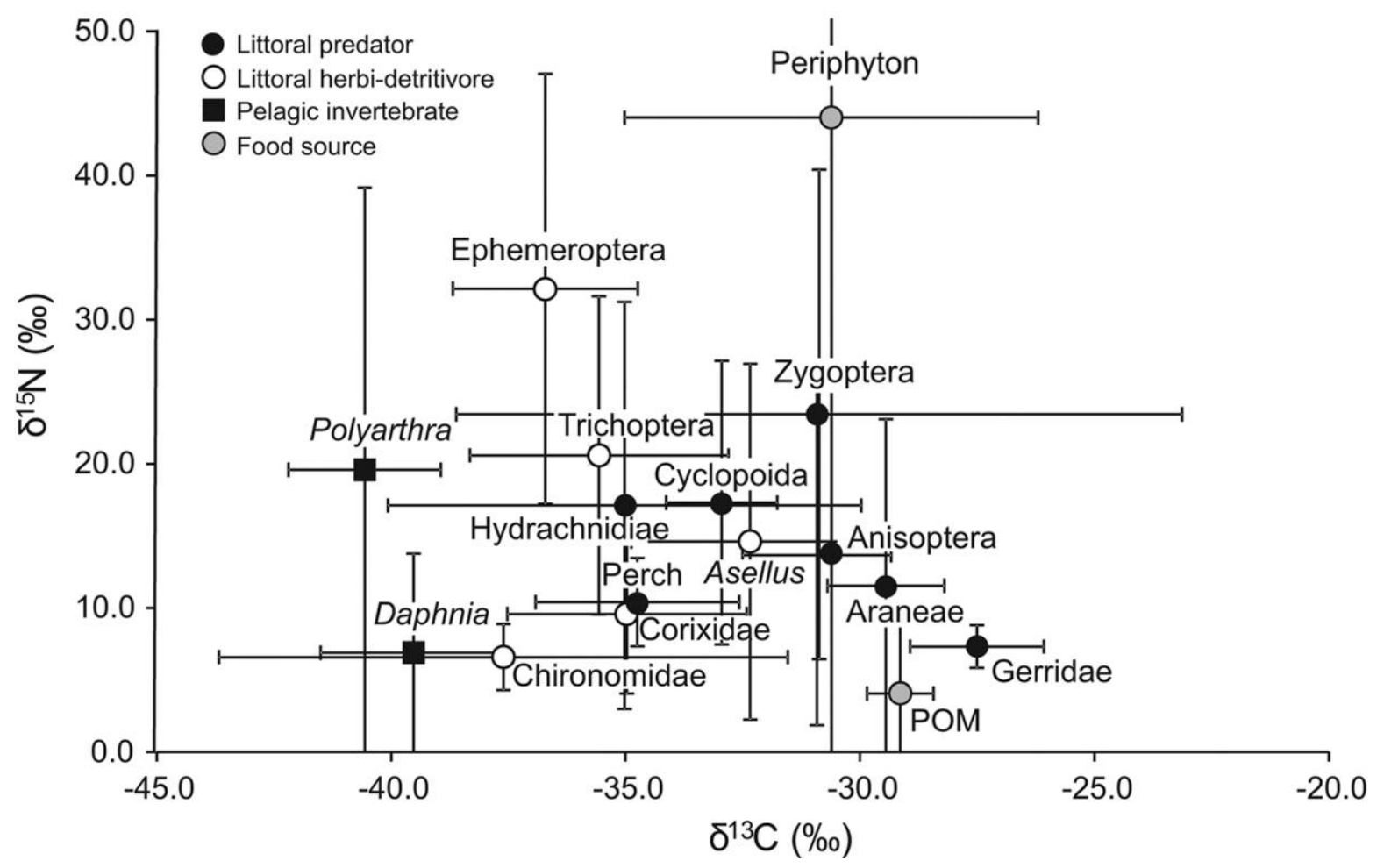

Figure 6. Biplot of the mean $( \pm \mathrm{SD}) \delta^{15} \mathrm{~N}$ and $\delta^{13} \mathrm{C}$ of different invertebrate taxa, perch and basal resources in Mekkojärvi in 2014.

that can sustain rich invertebrate communities. Littoral habitats remain underrepresented in limnological studies (Vadeboncoeur et al. 2002), but their importance to lake food webs and dynamics is increasingly being recognized. Our study demonstrates the important role of a littoral moss bed for invertebrate production in a highly humic lake and, together with our recent study (Vesterinen et al. 2016), shows that aquatic vegetation structure is a crucial variable that should be taken into account when estimating the importance of the littoral zone in humic lakes. Aquatic moss stands in small Finnish lakes have expanded in recent decades (Rintanen 1996), so their importance to aquatic invertebrate production presumably is increasing as well. Our results also indicate that in fishless lakes where littoral and pelagic zones have a similar structure to that in Mekkojärvi, these 2 habitats are not strongly coupled via zooplankton. However, our data suggest that the presence of fish can change the role of zooplankton by increasing predation pressure and affecting their behavior and spatial distribution.

Our study demonstrates the utility of the simple approach of adding ${ }^{15} \mathrm{NH}_{4}{ }^{15} \mathrm{NO}_{3}$ onto littoral moss vegetation to increase the $\delta^{15} \mathrm{~N}$ signature of periphyton assemblages in a dystrophic lake. $\delta^{15} \mathrm{~N}$ of periphyton increased to well above the natural abundance after every addition. Our assumption of rapid uptake of ${ }^{15} \mathrm{NH}_{4}{ }^{15} \mathrm{NO}_{3}$ by periphyton with no marked spread of the label into the pelagic zone for uptake by phytoplankton was supported because the $\delta^{15} \mathrm{~N}$ values of pelagic POM and Daphnia did not increase substantially. We suggest that the exceptional $\delta^{15} \mathrm{~N}$ of Daphnia in the Fish+ basin on 17 July can be explained by the presence of the introduced perch, which forced Daphnia in that basin into the littoral zone to seek refuge from predation, where they were locally exposed to the ${ }^{15} \mathrm{~N}$ label and possibly used ${ }^{15} \mathrm{~N}$-enriched littoral food sources. Fish presumably also forced cyclopoids to spend more time in the littoral zone, thereby accounting for the different isotope values of Cyclopoida between basins in August. A pattern of slowly increasing $\delta^{15} \mathrm{~N}$ of Daphnia toward the autumn also was seen in the Fish- basin, which may indicate some coupling between the pelagic and littoral zones or could be explained by the apparently natural increase in $\delta^{15} \mathrm{~N}$ values of different organisms in Mekkojärvi from spring to autumn seen in previous years. The differences in the $\delta^{15} \mathrm{~N}$ of zooplankton in time and between the treatment basins were not tested statistically because the isotope values were derived from bulk samples consisting of hundreds to thousands of individuals. Considering the large sample size with numerous individuals, the observed differences can be considered meaningful. We did not see an increase in $\delta^{15} \mathrm{~N}$ of POM, so Daphnia apparently did not become labeled via pelagic phytoplankton, although we might have missed a possible rapid increase in POM because it was not sampled as frequently as 
2013
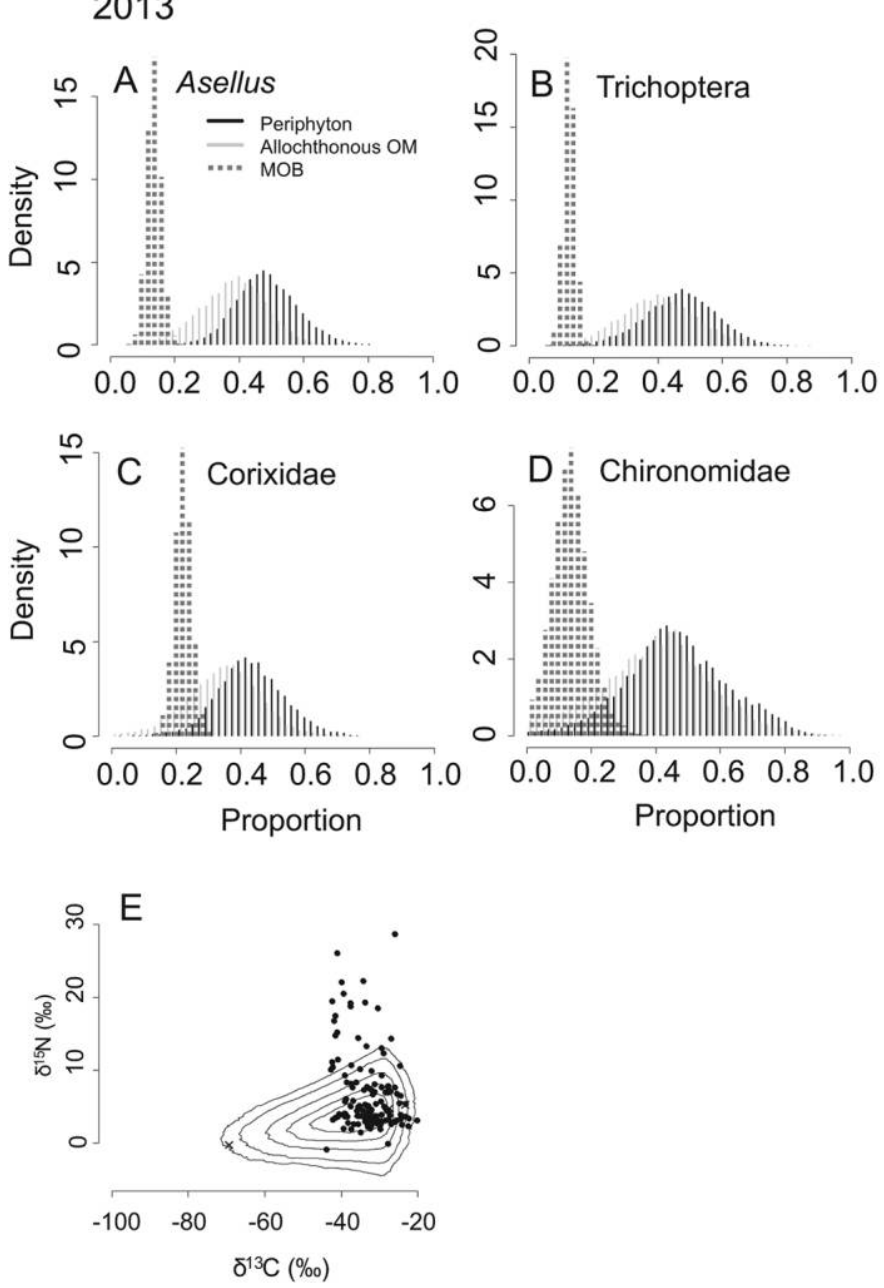

2014
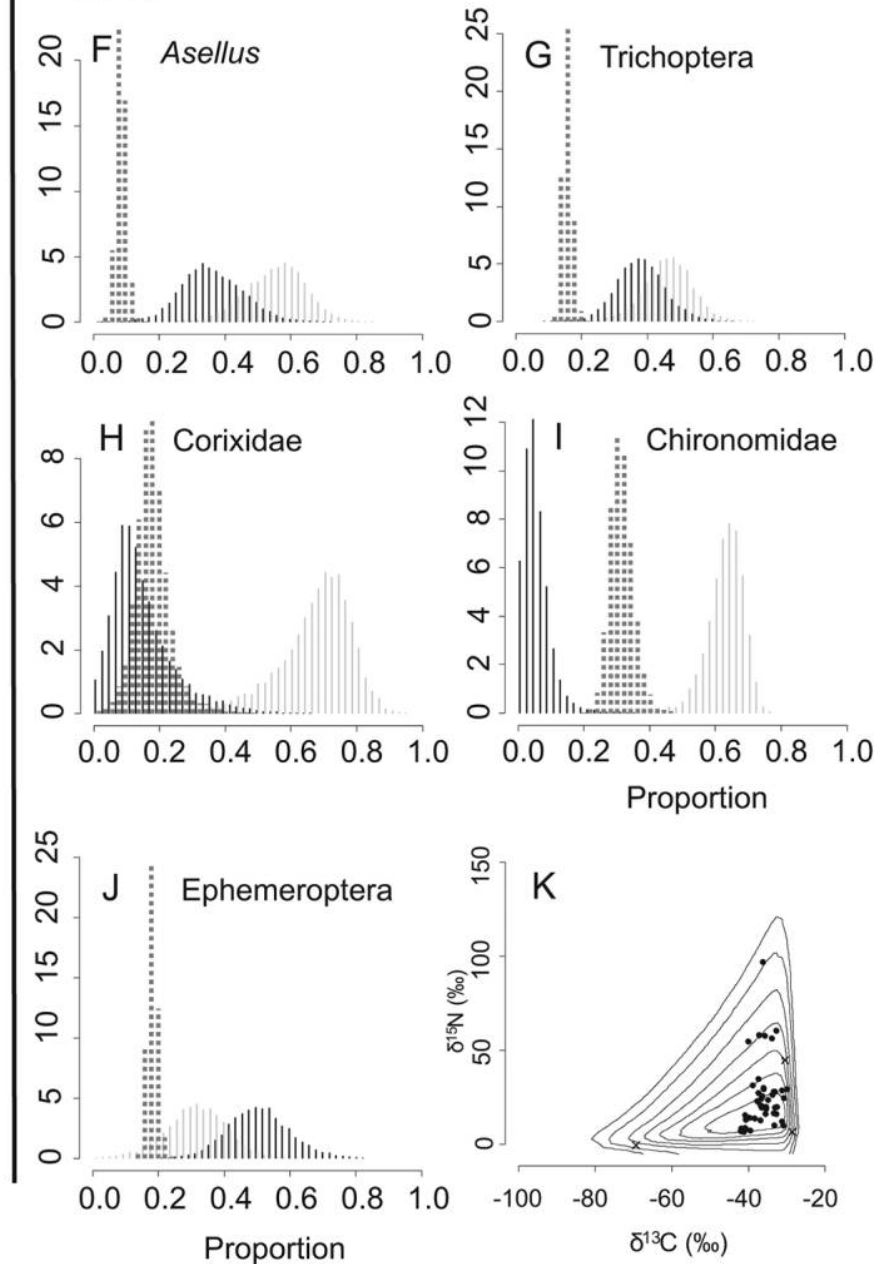

Figure 7. Probability histograms for the source contributions for littoral Asellus (A, F), Trichoptera (B, G), Corixidae (C, H), Chironomidae (D, I), and Ephemeroptera (J) diets using the Bayesian mixing model SIAR with 3 possible food sources: periphyton, allochthonous organic matter $(\mathrm{OM}$; value = that of particulate $\mathrm{OM})$ and methane-oxidizing bacteria (MOB; values from Taipale et al. 2008) in 2013 without isotope additions (A-D) and 2014 with ${ }^{15} \mathrm{NH}_{4}{ }^{15} \mathrm{NO}_{3}$ added to the littoral zone (F-J). Monte Carlo simulations of mixing polygons (Smith et al. 2013) for the 2013 data are presented in panel $\mathrm{E}$ and for the 2014 data in panel $\mathrm{K}$.

periphyton. These results indicate that the pelagic and littoral food webs in this naturally fishless lake are not strongly coupled via zooplankton. Our data from 2013 support this conclusion because the ${ }^{15} \mathrm{NH}_{4}{ }^{15} \mathrm{NO}_{3}$ additions made that year into the pelagic clearly increased the $\delta^{15} \mathrm{~N}$ values of Daphnia, whereas no increase was seen in the values for littoral invertebrates or periphyton.

The first isotope addition in late June 2014 appeared to label periphyton slightly more efficiently in the Fish+ than the Fish- basin, but the difference was not statistically significant. However, the difference may explain the apparently faster, but not statistically significant, increase in $\delta^{15} \mathrm{~N}$ values of invertebrates in the Fish + basin during the sampling period. The $\delta^{15} \mathrm{~N}$ values of herbi-detritivores started to decrease in September, following the senescence of pe- riphyton in late autumn, whereas the values of predators continued to increase until November. Slower turnover and growth rate of large-bodied predators compared to herbidetritivores, together with slow turnover of the foodweb transfers from nutrient through primary producer to herbidetritivore and then on to predator, leads to a lag in accumulation of the label in predators (O'Reilly et al. 2002, Fry 2006b) and may explain these differences.

A slight increase in $\delta^{15} \mathrm{~N}$ of perch was observed during their time in the lake. The low efficiency with which perch were recaptured with traps meant rather long intervals during the sampling period, and most of the sampled perch were recaptured in late September. The isotope values of these fishes reflect their diet during the growing season because the turnover of muscle tissue is slow (Perga and Ger- 
deaux 2005). Only one of the 33 individuals recaptured and analyzed showed markedly higher $\delta^{15} \mathrm{~N}$, indicating that this individual had relied more than others on ${ }^{15} \mathrm{~N}$-labeled littoral food sources. This exceptional individual resulted in a higher mean $\delta^{15} \mathrm{~N}$ value for perch and relatively high variation in late September. As mobile consumers, fish are integrators of pelagic and littoral habitats (Schindler and Scheuerell 2002), so we were surprised that only 1 perch was markedly ${ }^{15} \mathrm{~N}$-labeled. Our results indicate only weak coupling of the 2 habitats via perch. Large daphnids in the pelagic zone were evidently favored prey for perch, but we expected a shift in perch diet from pelagic zooplankton to littoral invertebrates once the large cladocerans had been grazed from the basin. However, the time the perch spent in the lake may have been insufficient to cause any marked increase in the $\delta^{15} \mathrm{~N}$ of the perch muscle tissue because of slow accumulation of the label in these mature and slowgrowing individuals with long tissue turnover times. Moreover, the dense moss mat presumably offers invertebrates efficient shelter from predation, so the ability of the perch to capture ${ }^{15} \mathrm{~N}$-labeled invertebrates in the littoral probably was restricted.

The isotope biplot revealed that pelagic Daphnia and Polyarthra had the most negative $\delta^{13} \mathrm{C}$ values, whereas POM, Gerridae, and Araneae had the least negative values. POM in Mekkojärvi is overwhelmingly of allochthonous origin. Gerrids living and feeding on the surface film primarily exploit terrestrial prey (Spence and Andersen 1994), which also is important in the diet of spiders in the genus Dolomedes (Zimmermann and Spence 1989), and is likely to account for the less negative $\delta^{13} \mathrm{C}$ of these taxa. Most of the littoral invertebrate taxa were positioned between the highly ${ }^{13} \mathrm{C}$-depleted pelagic zooplankton and the rather ${ }^{13} \mathrm{C}$-enriched Gerridae in the isotope biplot. Hence, most invertebrate taxa were rather ${ }^{13} \mathrm{C}$-depleted, which is common in lakes with high DOC and respired inorganic $\mathrm{C}$ (Premke et al. 2010). However, chironomids had the lowest $\delta^{13} \mathrm{C}$ values among the littoral invertebrates. This low $\delta^{13} \mathrm{C}$ could reflect inclusion of highly ${ }^{13} \mathrm{C}$-depleted $\mathrm{MOB}$ in their diet, and many chironomid larvae are well-documented users of MOB (e.g., Jones et al. 2008, Premke et al. 2010). Taipale et al. (2008) derived a highly negative estimate of $\delta^{13} \mathrm{C}$ for MOB in Mekkojärvi (-69.8 $\pm 10.0 \%$ o) and reported that pelagic Daphnia in Mekkojärvi feed extensively on MOB. The rotifer Polyarthra, which also showed very low $\delta^{13} \mathrm{C}$ values in our study, also may have been consuming MOB. In steeply stratified Mekkojärvi, where total anoxia extends near to the surface, an oxic-anoxic interface can be found in the littoral vegetation. This interface would provide a habitat where MOB are expected to be abundant (Jones and Grey 2011), so invertebrates associated with the moss mat probably have access to MOB in Mekkojärvi. The strongly depleted $\delta^{13} \mathrm{C}$ values of these taxa, particularly chironomids and ephemeropterans, probably are the result of a contribution from $\mathrm{MOB}$ to their diets. Based on fatty acid analysis, methane-derived $C$ contributes to invertebrate diets in humic bog pools in Estonia (van Duinen et al. 2013). van Duinen et al. (2013) also found clearly lower $\delta^{13} \mathrm{C}$ values in periphyton than in invertebrates (except zooplankton), suggesting that MOB associated with periphyton may oxidize $\mathrm{CH}_{4}$ to ${ }^{13} \mathrm{C}$-depleted $\mathrm{CO}_{2}$, which is then assimilated by the algae. The strongly ${ }^{13} \mathrm{C}$-depleted periphyton was then consumed by invertebrates. In contrast, our data, in which many invertebrate taxa were more ${ }^{13} \mathrm{C}$-depleted than periphyton, support the idea of a direct pathway from $\mathrm{MOB}$ to littoral invertebrates.

The SIAR mixing model provided estimates for the relative proportions of 3 food sources in the diets of herbidetritivores. The model for the 2014 data, in which the periphyton had been labeled by the ${ }^{15} \mathrm{~N}$ additions to give it a more distinctive isotope signature, was statistically more appropriate than the model for the 2013 data and more reasonable, highlighting the particular importance of periphyton in the diets of Asellus, Trichoptera, and Ephemeroptera, all of which are well-known grazers of periphyton. The model also indicated a higher proportion of allochthonous $\mathrm{OM}$ in the diet of Corixidae, which tend to feed on plant material from the water surface, and higher contributions of both allochthonous $\mathrm{OM}$ and $\mathrm{MOB}$ in the diets of chironomids. However, these results should be treated as only indicative because the turnover rate of ${ }^{15} \mathrm{~N}$ in periphyton was rather fast and the accumulation of the ${ }^{15} \mathrm{~N}$ label into consumer tissues was slower, which creates uncertainties in distinguishing $\delta^{15} \mathrm{~N}$ values of allochthonous OM and periphyton. To mitigate this problem by reducing temporal variation, we used the invertebrate isotope data from autumn for modeling, when the $\delta^{15} \mathrm{~N}$ values had reached or were close to maximum. We recognize that this approach has limitations because it is based on the assumption that static mean values represent what is actually a dynamic situation of changing isotope values. In principle, a more elegant way to handle such temporally dynamic isotope data might be to fit autoregressive models (e.g., Carpenter et al. 2005), but our data lacked the sampling frequency of all the end members for such analyses to be appropriate. In view of the longer lag time for accumulation of the ${ }^{15} \mathrm{~N}$ label into predator tissue, we did not run the mixing model for predators.

Since older unlabeled autochthonous detrital periphyton can significantly support invertebrate production (Solomon et al. 2008), the SIAR mixing model is likely to have overestimated the proportion of allochthonous OM in the diets of certain taxa. Also, some taxa like Trichoptera and Ephemeroptera were hard to find in the spring and appeared later in the summer, when most of the periphyton was already labeled. Individuals of Asellus, in turn, were seen early in the spring, over a month before the isotope additions, so unlabeled periphyton must have contributed to their diets.

An advantage of using ${ }^{15} \mathrm{NH}_{4}{ }^{15} \mathrm{NO}_{3}$ was the ability to label the whole biofilm of periphyton and associated bacteria, both of which are a potential food source for pelagic 
Daphnia. However, this approach did not allow separation of heterotrophic and autotrophic components of the biofilm in the diets of littoral invertebrates. Use of allochthonous DOM by bacteria and grazing of bacteria by protozoa (Tulonen et al. 1992), which are abundant in the littoral zone in Mekkojärvi (Kairesalo et al. 1992), is a possible pathway for allochthonous energy to reach littoral invertebrates. However, considering the generally higher nutritional quality of algae than allochthonous OM (Brett et al. 2009, Taipale et al. 2014), the very high primary production by periphyton in Mekkojärvi (Vesterinen et al. 2016), and the temporally dynamic isotope data that complicate the mixing models (Fry 2006a), the supposition that the highly accessible and higher-quality periphyton could be an even more important basal food resource for most littoral invertebrates than estimated by the SIAR model is reasonable.

Previous studies revealed that a significant proportion of the littoral macroinvertebrate community in Mekkojärvi consisted of large predatory taxa, such as odonates and notonectids (Kairesalo et al. 1992, Zúñiga 2011), similar to other fishless lakes (e.g., Blois-Heulin et al. 1990, Johansson et al. 2006, Schilling et al. 2009). However, these previous studies in Mekkojärvi were semiquantitative, creating uncertainty for estimating abundance relationships of macroinvertebrates. Zúñiga (2011) used hand-net sampling and activity traps, which were considered most appropriate for sampling the very complex littoral moss mat. The difficulty in quantitatively sampling the loose and relatively thick moss mat together with the patchy distribution of certain invertebrates can lead to serious underrepresentation of some taxa in data sets. Furthermore, some species are very mobile and difficult to capture with a hand net. We did not quantify the abundances of macroinvertebrates, but the relatively large proportion of predators was clearly evident in our samples. Alternative explanations for the dominance by predatory invertebrates in these lakes have been put forward. Kairesalo et al. (1992) suggested that the abundant predatory taxa and generally more diverse invertebrate community in the littoral than in the pelagic zone in Mekkojärvi probably are supported mainly by littoral primary producers. Aarniosalo (2007) used SIA to study whether predatory macroinvertebrates, Odonata and Notonecta, in the littoral zone of Mekkojärvi might be supported partly by pelagic Daphnia. She found no evidence that Daphnia contributed to the diets of Odonata, but proposed that notonectids might have fed on Daphnia. Our results indicate that the pelagic and littoral food webs are not strongly coupled via zooplankton, so the energy requirement for most of the predatory macroinvertebrates probably is derived mainly from primary production in the littoral zone and, to some extent, from terrestrial sources via a microbial pathway and from MOB. We did not obtain enough notonectids for data analysis, but as highly mobile predators, they presumably move between littoral and pelagic and potentially could feed on Daphnia. Considering the difficulty of quantitative estimation of the true macroinvertebrate abundances in Mekkojärvi and similar lakes, we think it reasonable to suggest that the smaller prey taxa exploited by predators have been underrepresented in previous studies, which could partly explain the apparent predator dominance.

Decomposition of terrestrial $\mathrm{C}$ is the primary source of $\mathrm{CO}_{2}$ in Finnish lakes during winter before ice melt (Kortelainen et al. 2006). Vesterinen et al. (2016) reported very high littoral primary production and biomass development by the periphyton in Mekkojärvi throughout the summer of 2012. Our current data indicate that, although periphyton contributes significantly to the diet of littoral invertebrates, only a small fraction of the high periphyton production reported by Vesterinen et al. (2016) is used by the consumers and the remaining periphyton biomass is ultimately decomposed by heterotrophs during autumn and winter. Lack of reliable estimates for the secondary production in Mekkojärvi prevents quantitative estimates of the absolute fate of periphyton production. Moreover, burial rates are difficult to quantify at short time scales. This problem has been identified as a current shortcoming in analyzing the $\mathrm{C}$ load and its various fates in lakes (Hanson et al. 2015). These issues will have to be resolved in the future.

The astonishingly high primary productivity reported by Vesterinen et al. (2016) provides an abundant autochthonous basal resource for consumers in Mekkojärvi, and our data clearly demonstrate high use of periphyton by littoral macroinvertebrates. Our finding further demonstrates the need for a holistic whole-lake ecosystem approach to investigating humic lakes. The SIA indicates that fish promoted coupling of pelagic and littoral pathways and that in the absence of fish these habitats remained relatively distinct. The behaviorally induced shift in resource use by zooplankton further demonstrates the role of fish as ecosystem integrators. Continued focus on littoral dynamics of the trophic structure, biogeochemistry, and metabolism of humic lakes is needed to develop a complete understanding of the ecology of these globally abundant systems.

\section{ACKNOWLEDGEMENTS}

Author contributions: JV, JS, SPD, and RIJ designed the study, JV and JS conducted the study, JV analyzed the data, and JV, JS, SPD, and RIJ wrote the paper.

We thank Lammi Biological Station for financial support to JV and for providing accommodation and laboratory facilities. We also acknowledge financial support from the Maj and Tor Nessling Foundation, The Academy of Finland (project 137671), the Marie Skłodowska-Curie actions (660655) under the EU Horizon 2020, and the Doctoral Programme in Biological and Environmental Science of the University of Jyväskylä.

\section{LITERATURE CITED}

Aarniosalo, P. 2007. Littoral-pelagic zone food web interactions in fishless, highly humic Lake Mekkojärvi. MS Thesis, University of Jyväskylä, Jyväskylä, Finland.

Ask, J., J. Karlsson, L. Persson, P. Ask, P. Byström, and M. Jansson. 2009. Terrestrial organic matter and light penetration: ef- 
fects on bacterial and primary production in lakes. Limnology and Oceanography 54:2034-2040.

Blois-Heulin, C., P. Crowley, M. Arrington, and D. M. Johnson. 1990. Direct and indirect effects of predators on the dominant invertebrates of two freshwater littoral communities. Oecologia (Berlin) 84:295-306.

Bowling, L., and K. Salonen. 1990. Heat uptake and resistance to mixing in small humic forest lakes in southern Finland. Australian Journal of Marine and Freshwater Research 41:747-759.

Brett, M. T., M. J. Kainz, S. J. Taipale, and H. Seshan. 2009. Phytoplankton, not allochthonous carbon, sustains herbivorous zooplankton production. Proceedings of the National Academy of Sciences of the United States of America 106:21197-21201.

Carpenter, S. R., J. J. Cole, M. L. Pace, M. van de Bogert, D. L. Bade, D. Bastviken, C. M. Gille, J. R. Hodgson, J. F. Kitchell, and E. Kritzberg. 2005. Ecosystem subsidies: terrestrial support of aquatic food webs from ${ }^{13} \mathrm{C}$ addition to contrasting lakes. Ecology 86:2737-2750.

Covich, A., M. Palmer, and T. Crowl. 1999. The role of benthic invertebrate species in freshwater ecosystems: zoobenthic species influence energy flows and nutrient cycling. BioScience 49: 119-127.

Craig, N., S. E. Jones, B. C. Weidel, and C. T. Solomon. 2015. Habitat, not resource availability, limits consumer production in lake ecosystems. Limnology and Oceanography 60:2079-2089.

Devlin, S. P., J. Saarenheimo, J. Syväranta, and R. I. Jones. 2015. Top consumer abundance influences lake methane efflux. $\mathrm{Na}$ ture Communications 6:8787.

Devlin, S. P., M. J. Vander Zanden, and Y. Vadeboncoeur. 2013. Depth-specific variation in carbon isotopes demonstrates resource partitioning among the littoral zoobenthos. Freshwater Biology 53:2389-2400.

Fry, B. 2006a. Isotope additions. Pages 183-193 in Stable isotope ecology. Springer Science+Business Media, New York.

Fry, B. 2006b. Technical supplement 6A in Stable isotope ecology. Springer Science+Business Media, New York.

Hanson, P. C., M. L. Pace, S. R. Carpenter, J. J. Cole, and E. H. Stanley. 2015. Integrating landscape carbon cycling: research needs for resolving organic carbon budgets of lakes. Ecosystems 18:363-375.

Johansson, F., G. Englund, T. Brodin, and H. Gardfjell. 2006. Species abundance models and patterns in dragonfly communities: effects of fish predators. Oikos 114:27-36.

Jones, R. I. 1992. The influence of humic substances on lacustrine planktonic food chains. Hydrobiologia 229:73-91.

Jones, R. I., C. Carter, A. Kelly, S. Ward, D. J. Kelly, and J. Grey. 2008. Widespread contribution of methane-cycle bacteria to the diets of lake profundal chironomid larvae. Ecology 89:857-864.

Jones, R. I., and J. Grey. 2011. Biogenic methane in freshwater food webs. Freshwater Biology 56:213-229.

Jones, S. E., C. T. Solomon, and B. C. Weidel. 2012. Subsidy or subtraction: how do terrestrial inputs influence consumer production in lakes? Freshwater Reviews 5:37-49.

Kairesalo, T., A. Lehtovaara, and P. Saukkonen. 1992. Littoralpelagial interchange and the decomposition of dissolved organic matter in a polyhumic lake. Hydrobiologia 229:199-224.

Karlsson, J., M. Berggren, J. Ask, P. Byström, A. Jonsson, H. Laudon, and M. Jansson. 2012. Terrestrial organic matter support of lake food webs: evidence from lake metabolism and stable hydrogen isotopes of consumers. Limnology and Oceanography 57:1042-1048.

Karlsson, J., P. Byström, J. Ask, P. Ask, L. Persson, and M. Jansson. 2009. Light limitation of nutrient-poor lake ecosystems. Nature 460:506-509.

Kortelainen, P., M. Rantakari, J. T. Huttunen, T. Mattsson, J. Alm, S. Juutinen, T. Larmola, J. Silvola, and P. J. Martikainen. 2006. Sediment respiration and lake trophic state are important predictors of large $\mathrm{CO}_{2}$ evasion from small boreal lakes. Global Change Biology 12:1554-1567.

Lau, D. C., I. Sundh, T. Vrede, J. Pickova, and W. Goedkoop. 2014. Autochthonous resources are the main driver of consumer production in dystrophic boreal lakes. Ecology 95:1506-1519.

O'Reilly, C. M., R. E. Hecky, A. S. Cohen, and P. Plisnier. 2002. Interpreting stable isotopes in food webs: recognizing the role of time averaging at different trophic levels. Limnology and Oceanography 47:306-309.

Pace, M. L., J. J. Cole, S. R. Carpenter, J. F. Kitchell, J. R. Hodgson, M. Bogert, D. L. Bade, E. S. Kritzberg, and D. Bastviken. 2004. Whole-lake carbon-13 additions reveal terrestrial support of aquatic food webs. Nature 427:240-243.

Parnell, A. C., R. Inger, S. Bearhop, and A. L. Jackson. 2010. Source partitioning using stable isotopes: coping with too much variation. PLOS ONE 5:e9672.

Perga, M., and D. Gerdeaux. 2005. 'Are fish what they eat' all year round? Oecologia Berlin 144:598-606.

Premke, K., J. Karlsson, K. Steger, C. Gudasz, E. von Wachenfeldt, and L. J. Tranvik. 2010. Stable isotope analysis of benthic fauna and their food sources in boreal lakes. Lournal of the North American Benthological Societv 29:1339-1348.

Rintanen, T. 1996. Changes in the flora and vegetation of 113 Finnish lakes during 40 years. Annales Botanici Fennici 33: 101-122.

Schilling, E. G., C. S. Loftin, and A. D. Huryn. 2009. Macroinvertebrates as indicators of fish absence in naturally fishless lakes. Freshwater Biology 54:181-202.

Schindler, D., and M. Scheuerell. 2002. Habitat coupling in lake ecosystems. Oikos 98:177-189.

Smith, J. A., D. Mazumder, I. M. Suthers, and M. D. Taylor. 2013. To fit or not to fit: evaluating stable isotope mixing models using simulated mixing polygons. Methods in Ecology and Evolution 4:612-618.

Solomon, C. T., S. R. Carpenter, M. K. Clayton, J. J. Cole, J. J. Coloso, M. L. Pace, M. Vander Zanden, and B. C. Weidel. 2011. Terrestrial, benthic, and pelagic resource use in lakes: results from a three-isotope Bayesian mixing model. Ecology 92:1115-1125.

Solomon, C. T., S. R. Carpenter, J. J. Cole, and M. L. Pace. 2008. Support of benthic invertebrates by detrital resources and current autochthonous primary production: results from a whole-lake ${ }^{13} \mathrm{C}$ addition. Freshwater Biology 53:42-54.

Spence, J. R., and N. M. Andersen. 1994. Biology of water striders: interactions between systematics and ecology. Annual Review of Entomology 39:101-128.

Taipale, S. J., M. T. Brett, M. W. Hahn, D. Martin-Creuzburg, S. Yeung, M. Hiltunen, U. Strandberg, and P. Kankaala. 2014. Differing Daphnia magna assimilation efficiencies for terrestrial, bacterial, and algal carbon and fatty acids. Ecology 95: 563-576. 
Taipale, S., P. Kankaala, and R. I. Jones. 2007. Contributions of different organic carbon sources to Daphnia in the pelagic foodweb of a small polyhumic lake: results from mesocosm DI13C-additions. Ecosystems 10:757-772.

Taipale, S., P. Kankaala, M. Tiirola, and R. I. Jones. 2008. Wholelake dissolved inorganic ${ }^{13} \mathrm{C}$ additions reveal seasonal shifts in zooplankton diet. Ecology 89:463-474.

Tulonen, T., K. Salonen, and L. Arvola. 1992. Effects of different molecular weight fractions of dissolved organic matter on the growth of bacteria, algae and protozoa from a highly humic lake. Hydrobiologia 229:239-252.

Vadeboncoeur, Y., E. Jeppesen, M. Vander Zanden, H. Schierup, K. Christoffersen, and D. M. Lodge. 2003. From Greenland to green lakes: cultural eutrophication and the loss of benthic pathways in lakes. Limnology and Oceanography 48:14081418.

Vadeboncoeur, Y., G. Peterson, M. Vander Zanden, and J. Kalff. 2008. Benthic algal production across lake size gradients: interactions among morphometry, nutrients, and light. Ecology 89:2542-2552.

Vadeboncoeur, Y., M. Vander Zanden, and D. M. Lodge. 2002. Putting the lake back together: reintegrating benthic pathways into lake food web models. BioScience 52:44-54.

Van de Meutter, F., R. Stoks, and L. de Meester. 2004. Behavioral linkage of pelagic prey and littoral predators: microhabitat selection by Daphnia induced by damselfly larvae. Oikos 107:265-272.
Vander Zanden, M., and J. B. Rasmussen. 1999. Primary consumer $\delta^{13} \mathrm{C}$ and $\delta^{15} \mathrm{~N}$ and the trophic position of aquatic consumers. Ecology 84:1395-1404.

Vander Zanden, M., and J. B. Rasmussen. 2001. Variation in $\delta^{15} \mathrm{~N}$ and $\delta^{13} \mathrm{C}$ trophic fractionation: implications for aquatic food web studies. Limnology and Oceanography 46:2061-2066.

van Duinen, G. A., K. Vermonden, P. L. E. Bodelier, A. J. Hendriks, R. S. E. W. Leuven, J. J. Middelburg, G. van der Velde, and W. C. E. P. Verberk. 2013. Methane as a carbon source for the food web in raised bog pools. Freshwater Science 32:1260-1272.

Vesterinen, J., S. P. Devlin, J. Syväranta, and R. I. Jones. 2016. Accounting for littoral primary production by periphyton shifts a highly humic boreal lake towards net autotrophy. Freshwater Biology 61:265-276.

Zimmermann, M., and J. R. Spence. 1989. Prey use of the fishing spider Dolomedes triton (Pisauridae, Araneae): an important predator of the neuston community. Oecologia (Berlin) 80: 187-194.

Zúñiga, J. C. 2011. Responses of littoral macroinvertebrates in a small humic lake to different fish predation regimes. MS Thesis, University of Jyväskylä, Jyväskylä, Finland.

Zwart, J. A., N. Craig, P. T. Kelly, S. D. Sebestyen, C. T. Solomon, B. C. Weidel, and S. E. Jones. 2015. Metabolic and physiochemical responses to a whole-lake experimental increase in dissolved organic carbon in a north-temperate lake. Limnology and Oceanography. doi:10.1002/lno.10248 